\title{
Optimization of media formulation for axillary shoot multiplication of the red-peeled sweet potato (Ipomoea batatas [L.] Lam.) 'Abees'
}

\author{
Yaser Hassan Dewir ${ }^{1,2^{*}}$, Abdulhakim A. Aldubai ${ }^{1,3}$, Mafatlal M. Kher ${ }^{4}$, Abdullah A. Alsadon ${ }^{1}$, \\ Salah El-Hendawy ${ }^{1,5}$, and Nasser A. Al-Suhaibani ${ }^{1}$
}

\author{
'King Saud University, College of Food \& Agriculture Sciences, P.O. Box 2460, Riyadh 11451, Saudi Arabia. \\ ${ }^{2}$ Kafrelsheikh University, Faculty of Agriculture, Kafr El-Sheikh 33516, Egypt. \\ "Corresponding author (ydewir@ksu.edu.sa). \\ ${ }^{3}$ Agriculture Research and Extension Authority, Sana'a 87148, Yemen. \\ ${ }^{4}$ Sardar Patel University, P.G. Department of Biosciences, Sardar Patel Maidan, Vadtal Road, Vallabh Vidyanagar, Gujarat 388120, India. \\ ${ }^{5}$ Suez Canal University, Faculty of Agriculture, Ismailia 41522, Egypt.
}

Received: 4 July 2019; Accepted: 2 October 2019; doi:10.4067/S0718-58392020000100003

\begin{abstract}
Sweet potato (Ipomoea batatas [L.] Lam.) is an important food crop that is cultivated and consumed worldwide, and its nutritional value makes it especially important in developing countries. However, sweet potato plants produced using conventional vegetative propagation can be prone to several diseases, thereby hindering crop yield. Therefore, micropropagation techniques are useful for producing higher quality plant material. The aim of the present study was to determine the optimal medium formulation for the axillary shoot multiplication of single-node 'Abees' explants. The influences of cytokinins (6-benzyladenine [BA], kinetin, thidiazuron, and zeatin), gibberellic acid, phenylacetic acid, indole-3-butyric acid, silver nitrate, and oxalic acid, culture duration, and medium salt strength were investigated. Optimal proliferation was observed when shoots were cultured on half-strength MS medium that was supplemented with $2 \mathrm{mg} \mathrm{L}^{-1}$ $\mathrm{BA}$ and $100 \mathrm{mg} \mathrm{L}^{-1}$ oxalic acid for $2 \mathrm{wk}$, followed by culture on half-strength MS medium without plant growth regulators for $4 \mathrm{wk}$. In this medium, the greatest number of shoots (3.1) and total number of nodes (16.1) per explant were observed. All $(100 \%)$ of the regenerated shoots were rooted and acclimatized, with a survival rate of $96 \%$ when transferred to $e x$ vitro conditions and no morphological abnormalities.
\end{abstract}

Key words: Convolvulaceae, culture duration, micropropagation, oxalic acid, phenylacetic acid, silver nitrate.

\section{INTRODUCTION}

Sweet potato (Ipomoea batatas [L.] Lam; Convolvulaceae) is among the world's most important and versatile food crops (Bovell-Benjamin, 2007; Iese et al., 2018), ranking seventh among the most important food crops (Mukherjee et al., 2012) and third among the most important tuber and root food crops, after potato and cassava (FAOSTAT, 2016). Sweet potato is considered an important staple food and has been consumed and cultivated for more than $5000 \mathrm{yr}$ (Bovell-Benjamin, 2007; Loebenstein, 2009). For these reasons, sweet potato is attractive to agriculturist, ecologists, and economists that are interested in developing sustainable food production systems in the tropics (Bovell-Benjamin, 2007; Loebenstein, 2009; Mukherjee et al., 2012; Iese et al., 2018).

Because sweet potato is highly heterozygous, seeds are used only for breeding and the development of new cultivars and breeding lines (Gaba and Singer, 2009). Sweet potato is vegetatively propagated through storage roots, shoot tips, and stem cuttings (Gaba and Singer, 2009). However, plantlets produced using vegetative methods are sometimes infected 
with disease. In contrast, plantlets produced using micropropagation techniques are generally pathogen-free. Accordingly, plants produced using micropropagation are generally preferred over those produced using vegetative methods. Additionally, micropropagation methods have several advantages over conventional propagation. Micropropagation has been used for commercial scale propagation of many horticultural crops for production of quality planting material. Due to the presence of predetermined shoot meristems, nodal explants have become popular in sweet potato micropropagation. For example, nodal explants were used for the micropropagation of 'Carmen Rubin' and 'White Triumph' (Dolinski and Olek, 2013), 'Gaozi No. 1' (Gong et al., 2005), 'Naruto Kintoki' (Teixeira da Silva et al., 2007), 'KSP 36' and 'KEMB 36' (Mvuria and Ombori, 2014), and 30 accessions from the northern region of Rio de Janeiro, Brazil (Vettorazzi et al., 2017). However, little is known about the micropropagation of 'Abees' sweet potato. Studies on this cultivar have generally focused on indirect regeneration via somatic embryogenesis (Aboulila, 2016) and adventitious shoot proliferation (El Far et al., 2009; Ali et al., 2017), although, in regards to direct regeneration, El Far (2007) investigated the effects of plantgrowth regulators and sucrose concentrations on axillary shoot proliferation but overall low regeneration efficiency was reported. The Egyptian sweet potato I. batatas 'Abees' is a popular local cultivar that is characterized by its red peel and orange flesh (Marzouk et al., 2011) and that is considered a rich source of pro-vitamin A carotenoids (Teow et al., 2007; Marzouk et al., 2011). The efficacy of micropropagation techniques depends on a variety of factors, including genotype, stock plant physiology, season, basal medium composition, plant-growth regulators, light source (type and intensity), photoperiod, gelling agents, and C sources (George et al., 2008). The aim of the present study was to determine the effects of cytokinins (6-benzyladenine, kinetin, thidiazuron, and zeatin), gibberellic acid, phenylacetic acid, indole-3-butyric acid, silver nitrate, and oxalic acid, culture duration, and medium salt strength on the axillary shoot multiplication of single-node Ipomoea batatas ‘Abees' explants.

\section{MATERIALS AND METHODS}

\section{Explant collection, disinfection, and culture establishment}

Twigs (5-6 cm) of red-peeled Egyptian sweet potato (Ipomoea batatas [L.] Lam.) 'Abees' were excised from the actively growing shoots of stock plants grown and maintained at a local farm in Kafr El Sheikh Governorate, Egypt. The twigs were cleaned under running tap water for $10 \mathrm{~min}$ and rinsed three times using sterile distilled water. Then, twigs were disinfected by submerging them in $70 \%(\mathrm{v} / \mathrm{v})$ ethanol for $20 \mathrm{~s}$ and then transferring them to a $0.1 \%(\mathrm{w} / \mathrm{v})$ mercuric chloride solution that contained 2-3 drops of Tween 20 for $5 \mathrm{~min}$. Finally, twigs were rinsed three more times using sterile distilled water, and 0.5 to $1 \mathrm{~cm}$ twig segments (i.e., nodal explants) were cultured in glass test tubes $(24 \times 200 \mathrm{~mm})$ that contained $15 \mathrm{~mL}$ basal Murashige-Skoog (MS) medium (Murashige and Skoog, 1962), which had been supplemented with $3 \%(\mathrm{w} / \mathrm{v})$ sucrose and $0.8 \%(\mathrm{w} / \mathrm{v})$ agar-agar plugged with plastic caps. In vitro regenerated shoots (Figure 1A) were cut into nodal segments $(1 \mathrm{~cm}$, with one axillary bud), cultured in Magenta GA-7 culture vessels $(77 \times 77 \times 97 \mathrm{~mm}$; Sigma Chemical, St. Louis, Missouri, USA) that contained semisolid MS medium without plant growth regulators (PGRs). The regenerated shoots were then subcultured on the same medium every $4 \mathrm{wk}$ until enough plant material was available to conduct the experiments.

\section{Axillary shoot multiplication}

Nodal segments $(0.5-1.0 \mathrm{~cm}$, with one axillary bud) from the in vitro regenerated shoots (four explants per culture vessel) were inoculated to Magenta culture vessels that contained $50 \mathrm{~mL}$ MS medium that had been supplemented with different concentrations and combinations of PGRs and additives. For the first experiment, the MS medium was supplemented with different concentrations of various cytokinins, which included 6-benzyladenine (BA; 0-4 mg L $\mathrm{L}^{-1}$ ), kinetin (Kin; 0-7 mg L-1), thidiazuron (TDZ; 0-1.5 mg L-1), and zeatin (0-1.5 $\left.\mathrm{mg} \mathrm{L}^{-1}\right)$. For the second experiment, different combinations of BA $\left(2 \mathrm{mg} \mathrm{L}^{-1}\right)$, Kin $\left(5 \mathrm{mg} \mathrm{L}^{-1}\right)$, TDZ $\left(1 \mathrm{mg} \mathrm{L}^{-1}\right)$, and zeatin $\left(0.1 \mathrm{mg} \mathrm{L}^{-1}\right)$ were used, and for the third experiment, gibberellic acid $\left(\mathrm{GA}_{3} ; 0-1.0 \mathrm{mg} \mathrm{L}^{-1}\right)$, phenylacetic acid (PAA; $0-4 \mathrm{mg} \mathrm{L}^{-1}$ ), indole-3-butyric acid (IBA; 0-1 mg $\left.\mathrm{L}^{-1}\right)$, silver nitrate $\left(\mathrm{AgNO}_{3} ; 0-4.5 \mathrm{mg} \mathrm{L}^{-1}\right)$, and oxalic acid $\left(\mathrm{C}_{2} \mathrm{H}_{2} \mathrm{O}_{4} ; 0-300 \mathrm{mg} \mathrm{L}^{-1}\right)$ were combined with $\mathrm{BA}\left(2 \mathrm{mg} \mathrm{L}^{-1}\right)$. For the fourth experiment, MS salt concentration was varied (half- or full-strength), and the explants were exposed to PGRs for different lengths of time (1, 2,3, or $6 \mathrm{wk})$. The salts used for preparing the MS medium and PGRs were obtained from BDH Chemicals, Ltd. (Poole, UK). 
Figure 1. Micropropagation of Ipomoea batatas 'Abees': establishment of in vitro culture using node explant cultured on Murashige and Skoog's (MS) medium without plant growth regulators (PGRs) after 2 wk in culture (A), axillary shoot proliferation on half strength MS medium containing $2.0 \mathrm{mg} \mathrm{L}^{-1} \mathrm{BA}$ and $100 \mathrm{mg} \mathrm{L}^{-1}$ oxalic acid for 2 wk followed by culture on half strength MS medium without PGRs for $4 \mathrm{wk}(\mathrm{B})$, in vitro rooting of proliferated axillary shoots on half strength MS medium without PGRs after 3 wk (C), and acclimatized plantlets after $30 \mathrm{~d}$ in acclimatization (D).

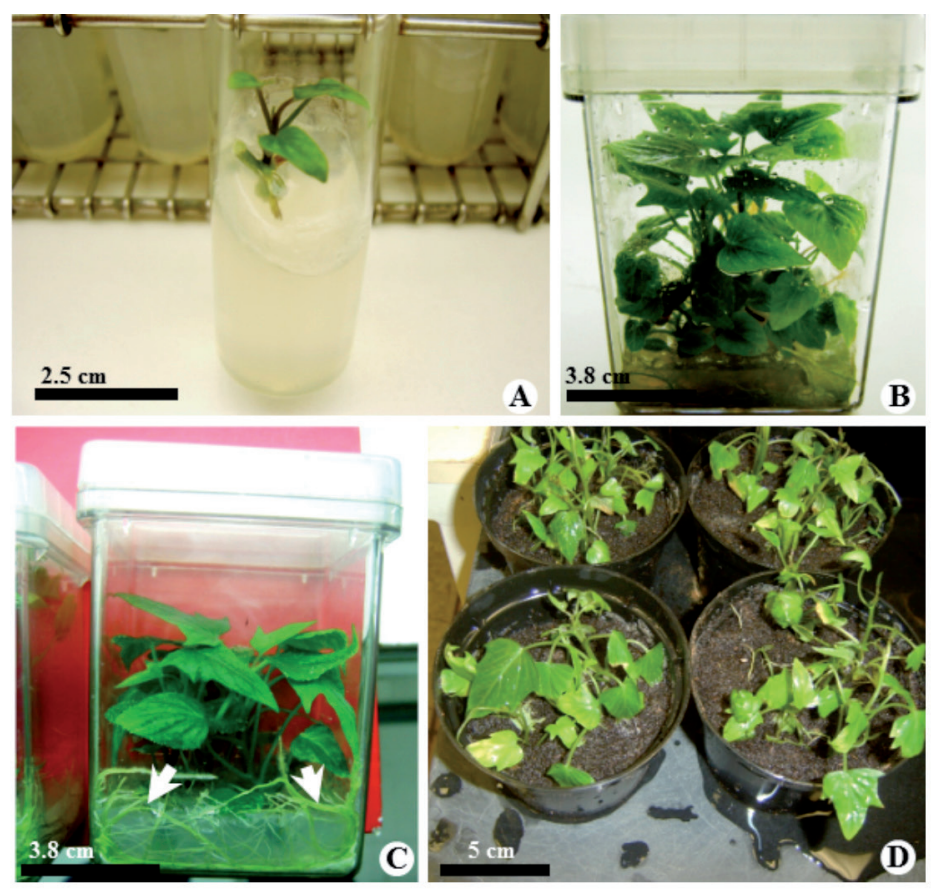

\section{In vitro culture conditions}

The MS medium was gelled using $0.8 \%(\mathrm{w} / \mathrm{v})$ agar-agar, and the $\mathrm{pH}$ of the medium was adjusted to 5.8 before autoclaving $\left(121^{\circ} \mathrm{C}\right.$ and $1.2 \mathrm{~kg} \mathrm{~cm}^{-2}$ for $\left.15 \mathrm{~min}\right)$. All cultures were incubated for $6 \mathrm{wk}$ at $25 \pm 2{ }^{\circ} \mathrm{C}$ under cool-white fluorescent lights that provided a 16:8 h photoperiod of $35 \mu \mathrm{mol} \mathrm{m} \mathrm{m}^{-2} \mathrm{~s}^{-1}$ photosynthetic photon flux density (PPFD).

\section{In vitro rooting and acclimatization}

Proliferated axillary shoots were transferred to half-strength MS medium without PGRs to allow rooting. After 3 wk, rooted plantlets $(5-7 \mathrm{~cm}$, with 4-5 roots) were gently removed from the medium, rinsed using tap water, briefly dipped (for few seconds) in a fungicide solution (0.5 $\mathrm{g} \mathrm{L}^{-1}$ Aromil-Plus $50 \mathrm{WP}$; Mobedco-Vet, Amman, Jordan), and finally transplanted into small plastic pots $(10 \mathrm{~cm}$ diameter $)$ that contained a 1:1 mixture of peat moss and sand. The potted plants were incubated at $25 \pm 2{ }^{\circ} \mathrm{C}, 50 \%-60 \% \mathrm{RH}$, and $100 \mu \mathrm{mol} \mathrm{m}{ }^{-2} \mathrm{~s}^{-1}$ PPFD $(16: 8 \mathrm{~h}$ photoperiod under white fluorescent lamps) for $20 \mathrm{~d}$ in a growth chamber (Model KBWF 720; Binder, Tuttlingen, Germany), with the pots being covered with transparent polyethylene for the first $10 \mathrm{~d}$. The plantlets were regularly irrigated using a nutrient solution that contained half-strength MS basal salts, and plantlet survival was evaluated at $30 \mathrm{~d}$ after being transferred to the growth chamber.

\section{Experimental design and data analysis}

The experiments were set up using a completely randomized design, with four replicates per treatment. Shoot number, shoot height, node number, fresh weight, and percentage of explants forming shoots were recorded after 6 wk of culture. Data expressed as percentages were arcsine-transformed before analysis (Compton, 1994), and the effects of the treatments were assessed using ANOVA and Tukey's range tests in SAS program (Version 6.12; SAS Institute, Cary, North Carolina, USA). 


\section{RESULTS AND DISCUSSION}

\section{Effects of cytokinins on axillary shoot multiplication}

Among the cytokine-supplemented cultures, all but 5-7 $\mathrm{mg} \mathrm{L}^{-1} \mathrm{Kin}$ and TDZ cultures yielded $100 \%$ shoot regeneration (Table 1). There was nonsignificant difference $(P \geq 0.05)$ in the number of shoots per node for the control, TDZ (0$\left.1.5 \mathrm{mg} \mathrm{L}^{-1}\right)$, zeatin $\left(0-1.5 \mathrm{mg} \mathrm{L}^{-1}\right)$, Kin $\left(1,3\right.$, and $\left.7 \mathrm{mg} \mathrm{L}^{-1}\right)$, and BA $\left(0.5\right.$ and $\left.2 \mathrm{mg} \mathrm{L}^{-1}\right)$ treatments, although the maximum number of shoots observed in the $2 \mathrm{mg} \mathrm{L}^{-1} \mathrm{BA}$ treatment (1.8 shoots per node) was significantly greater than the maximum number of shoots observed in the other treatments $(P \leq 0.05)$. However, the maximum shoot length observed on the control medium, additionally, shoots obtained from the control and $2 \mathrm{mg} \mathrm{L}^{-1} \mathrm{BA}$ supplemented medium had nonsignificant difference in fresh weight $(P \leq 0.05)$. Therefore, the results indicate that cytokinin type significantly affects regeneration potential $(P \leq 0.01)$, as well as the multiplication $(P \leq 0.01)$, length $(P \leq 0.001)$, and fresh weight $(P \leq 0.001)$ of regenerated shoots (Table 1). Nevertheless, cytokinin concentration failed to exhibit any significant effect on shoot multiplication.

The explants cultured on TDZ-supplemented medium formed callus at the basal parts. The low shoot regeneration observed in these cultures could have resulted in using high concentrations of TDZ (Dewir et al., 2018). The superiority of BA over TDZ has been reported previously for the axillary shoot multiplication of sweet potato 'cv. 11' and 'cv. 44', in which no multiple shoots were observed on TDZ-supplemented medium (Mohamed et al., 2007). For the axillary shoot multiplication of sweet potato 'Esprit', 'Lady Rosseta', and 'Meridian', BA produced better results than Kin (Bhuiyan, 2013). The superior effects of BA over other cytokinins on shoot regeneration have also been reported for other members of the Convolvulaceae, i.e. Merrimia quinquefolia (Kher et al., 2015). None of the tested cytokinin combinations significantly improved shoot regeneration over that of the control $(P \geq 0.05$, Table 2$)$. It is notable, however, that the media supplemented with $2 \mathrm{mg} \mathrm{L}^{-1} \mathrm{BA}, 5 \mathrm{mg} \mathrm{L}^{-1} \mathrm{Kn}$, and $1 \mathrm{mg} \mathrm{L}^{-1}$ TDZ produced significantly more shoots (2.6 per node, $P \leq 0.05)$ than the control, albeit with very low shoot regeneration frequency $(56 \%)$, shoot length $(1.2 \mathrm{~cm})$, and fresh weight $(0.27 \mathrm{~g})$. It is well-known that in vitro growth and morphogenesis are regulated by exogenously applied PGRs and the balance of endogenous hormones. Cytokinin-cytokinin combinations have been reported to ameliorate

Table 1. Effect of cytokinins on shoot multiplication and growth of Ipomoea batatas 'Abees' using a single node explant after $6 \mathrm{wk}$ in culture.

\begin{tabular}{|c|c|c|c|c|c|}
\hline Cytokinins & $\begin{array}{l}\text { Concentration } \\
\text { of cytokinin }\end{array}$ & $\begin{array}{c}\text { Shoot } \\
\text { regeneration }\end{array}$ & Shoots & $\begin{array}{l}\text { Shoot } \\
\text { length }\end{array}$ & $\begin{array}{c}\text { Fresh } \\
\text { weight }\end{array}$ \\
\hline & $\mathrm{mg} \mathrm{L}^{-1}$ & $\%$ & Nr node ${ }^{-1}$ & $\mathrm{~cm}$ & g explant $^{-1}$ \\
\hline MS basal medium & (control) & $100 \mathrm{a}$ & $1.0 \mathrm{~b}$ & $6.9 \mathrm{a}$ & $0.92 \mathrm{a}$ \\
\hline \multirow[t]{4}{*}{ BA } & 0.5 & $100 \mathrm{a}$ & $1.0 \mathrm{~b}$ & $3.9 \mathrm{c}$ & $0.75 \mathrm{ab}$ \\
\hline & 1.0 & $100 \mathrm{a}$ & $1.6 \mathrm{ab}$ & $2.3 \mathrm{def}$ & $0.63 \mathrm{bcd}$ \\
\hline & 2.0 & $100 \mathrm{a}$ & $1.8 \mathrm{a}$ & 2.1def & $0.95 \mathrm{a}$ \\
\hline & 4.0 & $100 \mathrm{a}$ & $1.7 \mathrm{ab}$ & $1.8 \mathrm{efg}$ & $0.36 \mathrm{ef}$ \\
\hline \multirow[t]{4}{*}{ Kinetin } & 1.0 & $100 \mathrm{a}$ & $1.4 \mathrm{~b}$ & $4.9 \mathrm{~b}$ & $0.65 \mathrm{bcd}$ \\
\hline & 3.0 & $100 \mathrm{a}$ & $1.3 \mathrm{~b}$ & 2.1defg & $0.43 \mathrm{def}$ \\
\hline & 5.0 & $92 \mathrm{~b}$ & $1.7 \mathrm{ab}$ & $1.1 \mathrm{gh}$ & 0.37 ef \\
\hline & 7.0 & $92 b$ & $1.2 \mathrm{~b}$ & $1.6 \mathrm{fgh}$ & $0.45 \mathrm{cdef}$ \\
\hline \multirow[t]{4}{*}{ TDZ } & 0.1 & $42 \mathrm{~d}$ & $1.0 \mathrm{~b}$ & $1.9 \mathrm{efg}$ & $0.29 \mathrm{ef}$ \\
\hline & 0.5 & $42 \mathrm{~d}$ & $1.0 \mathrm{~b}$ & $1.2 \mathrm{gh}$ & $0.36 \mathrm{ef}$ \\
\hline & 1.0 & $50 \mathrm{c}$ & $1.2 \mathrm{~b}$ & $0.7 \mathrm{~h}$ & $0.42 \mathrm{def}$ \\
\hline & 1.5 & $50 \mathrm{c}$ & $1.2 \mathrm{~b}$ & $0.6 \mathrm{~h}$ & $0.56 \mathrm{bcde}$ \\
\hline \multirow[t]{4}{*}{ Zeatin } & 0.1 & $100 \mathrm{a}$ & $1.3 \mathrm{~b}$ & $3.0 \mathrm{~d}$ & $0.52 \mathrm{bcdef}$ \\
\hline & 0.5 & $100 \mathrm{a}$ & $1.0 \mathrm{~b}$ & $2.3 \mathrm{def}$ & $0.74 \mathrm{ab}$ \\
\hline & 1.0 & $100 \mathrm{a}$ & $1.0 \mathrm{~b}$ & $2.6 \mathrm{def}$ & $0.70 \mathrm{abc}$ \\
\hline & 1.5 & $100 \mathrm{a}$ & $1.2 \mathrm{~b}$ & $2.7 \mathrm{de}$ & $0.72 \mathrm{ab}$ \\
\hline \multicolumn{6}{|l|}{ Significance } \\
\hline \multicolumn{2}{|c|}{ Cytokinin type (CT) } & $* *$ & $* *$ & $* * *$ & $* * *$ \\
\hline \multicolumn{2}{|c|}{ Cytokinin concentration (CC) } & $*$ & NS & $* * *$ & NS \\
\hline \multicolumn{2}{|c|}{$\mathrm{CT} \times \mathrm{CC}$} & * & NS & $* * *$ & $* * *$ \\
\hline
\end{tabular}


Table 2. Effect of different cytokinin-cytokinin combinations on shoot multiplication and growth of Ipomoea batatas 'Abees' using a single node explant after $6 \mathrm{wk}$ in culture.

\begin{tabular}{|c|c|c|c|c|c|c|c|}
\hline \multicolumn{4}{|c|}{ Cytokinins } & \multirow{2}{*}{$\begin{array}{l}\text { Shoot } \\
\text { regeneration }\end{array}$} & \multirow[b]{2}{*}{ Shoots } & \multirow{2}{*}{$\begin{array}{l}\text { Shoot } \\
\text { length }\end{array}$} & \multirow{2}{*}{$\begin{array}{c}\text { Fresh } \\
\text { weight }\end{array}$} \\
\hline BA & Kinetin & TDZ & Zeatin & & & & \\
\hline$\longrightarrow$ & 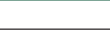 & $\mathrm{mg} \mathrm{L}^{-1}$ & - & $\%$ & $\mathrm{Nr}_{\text {node }}{ }^{-1}$ & $\mathrm{~cm}$ & g explant $^{-1}$ \\
\hline 2.0 & - & - & - & $100 \mathrm{a}$ & $1.9 b c$ & $2.3 b$ & $0.84 \mathrm{a}$ \\
\hline 2.0 & 5.0 & - & - & $75 c$ & $1.3 \mathrm{~cd}$ & $1.0 \mathrm{~cd}$ & $0.31 \mathrm{~cd}$ \\
\hline 2.0 & - & 1.0 & - & $75 c$ & $2.3 \mathrm{ab}$ & $1.2 \mathrm{~cd}$ & $0.40 \mathrm{bcd}$ \\
\hline \multirow[t]{8}{*}{2.0} & - & - & 0.1 & $69 c$ & $1.5 \mathrm{~cd}$ & $1.4 \mathrm{c}$ & $0.28 \mathrm{~cd}$ \\
\hline & 5.0 & - & - & $92 b$ & $1.7 \mathrm{bcd}$ & $1.1 \mathrm{~cd}$ & $0.37 \mathrm{bcd}$ \\
\hline & 5.0 & 1.0 & - & $56 \mathrm{~d}$ & $1.6 \mathrm{~cd}$ & $1.5 \mathrm{c}$ & $0.34 \mathrm{~cd}$ \\
\hline & 5.0 & - & 0.1 & $88 b$ & $1.3 \mathrm{~cd}$ & $2.7 \mathrm{ab}$ & $0.33 \mathrm{~cd}$ \\
\hline & - & 1.0 & - & $50 \mathrm{~d}$ & $1.2 \mathrm{~d}$ & $0.7 \mathrm{~d}$ & $0.42 b c$ \\
\hline & - & 1.0 & - & $94 b$ & $1.2 \mathrm{~d}$ & $1.2 \mathrm{~cd}$ & $0.37 \mathrm{bcd}$ \\
\hline & - & - & 0.1 & $100 \mathrm{a}$ & $1.3 \mathrm{~cd}$ & $2.9 \mathrm{a}$ & $0.52 b$ \\
\hline & - & - & 0.1 & $75 c$ & $1.5 \mathrm{~cd}$ & $1.2 \mathrm{~cd}$ & $0.24 d$ \\
\hline 2.0 & 5.0 & 1.0 & - & $56 \mathrm{~d}$ & $2.6 \mathrm{a}$ & $1.2 \mathrm{~cd}$ & $0.27 \mathrm{~cd}$ \\
\hline 2.0 & 5.0 & 1.0 & 0.1 & $100 \mathrm{a}$ & $1.9 \mathrm{bc}$ & $2.3 \mathrm{~b}$ & $0.84 \mathrm{a}$ \\
\hline
\end{tabular}

Values followed by the same letter in the same column are nonsignificantly different according to Tukey's test $(P \leq 0.05)$.

BA: 6-benzyladenine; TDZ: thidiazuron.

organogenesis in several plant species. Combinations of BA $\left(0.5-1.5 \mathrm{mg} \mathrm{L}^{-1}\right)$ and $\mathrm{Kin}\left(0.5-1.5 \mathrm{mg} \mathrm{L}^{-1}\right)$ have been reported to significantly enhance callus induction and adventitious shoot organogenesis in Solanum lycopersicum (Ali et al., 2012), and a combination of BA $\left(0.5 \mathrm{mg} \mathrm{L}^{-1}\right)$ and $\mathrm{Kin}\left(2 \mathrm{mg} \mathrm{L}^{-1}\right)$ was reported to increase adventitious shoot organogenesis from callus cultures in 'Kullufo' and 'Tulla' sweet potato (Mengs et al., 2018).

\section{Effects of other additives on axillary shoot multiplication}

The type and concentration of the other additives also had a significant impact on shoot number and shoot length (Table 3; $P \leq 0.001)$ but did not affect fresh weight $(P \geq 0.05)$. Several of the additives, namely $\mathrm{GA}_{3}$, PAA, IBA, and silver nitrate, promoted moderate shoot multiplication but had nonsignificant effect on shoot multiplication or fresh weight (Table 3). A previous study (El Far, 2007) found that neither IAA, NAA, nor GA 3 enhanced shoot proliferation in 'Abees' sweet potato but that $\mathrm{GA}_{3}$ enhanced shoot elongation. However, the combination of high concentration $\mathrm{GA}_{3}\left(10 \mathrm{mg} \mathrm{L}^{-1}\right)$ and $2 \mathrm{mg} \mathrm{L}^{-1} \mathrm{BA}$ improved adventitious shoot regeneration in 'Brondal' sweet potato to a mean of three shoots per meristem, with three nodes per shoot (Masekesa et al., 2016). Although silver nitrate has been used widely as an additive for in vitro propagation (Kumar et al., 2009), it failed to improve shoot multiplication in 'Abees' sweet potato, and although the combination of $2 \mathrm{mg} \mathrm{L}^{-1}$ $\mathrm{BA}$ and $100 \mathrm{mg} \mathrm{L}^{-1}$ oxalic acid significantly increased shoot number, maximum shoot length was observed on the medium that was supplemented with oxalic acid $\left(200 \mathrm{mg} \mathrm{L}^{-1}\right)$ alone. Oxalic acid is an antioxidant (Kayashima, 2002) that plays an important role in Ca regulation, plant defense, and detoxification (Franceschi and Nakata, 2005). However, few studies have examined the effects of oxalic acid on axillary shoot multiplication under in vitro conditions. Aika (2010) reported that oxalic acid (100 $\left.\mathrm{mg} \mathrm{L}^{-1}\right)$ enhanced shoot multiplication in Musa sp. 'Grand Naine' (7.8 shoots per explant), when compared to the control (2.1 shoots per explant). However, the stimulatory role of oxalic acid in shoot proliferation has yet to be determined.

\section{Effects of salt strength and exposure duration on axillary shoot multiplication}

Neither salt strength nor the interaction of salt strength and exposure duration significantly affected axillary shoot multiplication $(P \geq 0.05)$. However, exposure duration significantly affected the number of shoots per node $(P \leq 0.05)$, number of nodes per shoot $(P \leq 0.001)$, main shoot length $(P \leq 0.001)$, and total fresh weight $(P \leq 0.05)$. Shoot regeneration was greater when nodal explants were cultured for 2 wk and then transferred to PGR-free medium than when continuously cultured on multiplication medium for longer durations (Table 4). Nodal explants that were cultured on half-strength MS medium with BA $\left(2.0 \mathrm{mg} \mathrm{L}^{-1}\right)$ and oxalic acid $\left(100 \mathrm{mg} \mathrm{L}^{-1}\right)$ for 1-3 wk and then transferred to half-strength, PGR-free MS medium exhibited both root formation and shoot multiplication simultaneously (Figure 1B). The strategy of transferring the explants to a secondary PGR-free medium has also been reported to enhance shoot proliferation and elongation likely due to reducing or minimizing the carry-over effects of PGRs, thereby improving plant growth and circumventing growth abnormalities (Dewir et al., 2018). However, a similar two-step regeneration strategy, in which 'Abees' sweet potato 
Table 3. Effect of 6-benzyladenine (BA) in combination with additives on shoot multiplication and growth of Ipomoea batatas 'Abees' using a single node explant after $6 \mathrm{wk}$ in culture

\begin{tabular}{|c|c|c|c|c|}
\hline Additives & Concentration & Shoots & Shoot length & Fresh weight \\
\hline & $\mathrm{mg} \mathrm{L}^{-1}$ & $\mathrm{Nr}$ node $^{-1}$ & $\mathrm{~cm}$ & $g_{\text {explant }}{ }^{-1}$ \\
\hline Control & & $1.9 \mathrm{~cd}$ & $2.1 \mathrm{ab}$ & $0.81 \mathrm{a}$ \\
\hline \multirow[t]{3}{*}{$\mathrm{GA}_{3}$} & 0.1 & $2.2 \mathrm{bc}$ & $1.2 \mathrm{cdef}$ & $0.26 \mathrm{de}$ \\
\hline & 0.5 & $2.0 \mathrm{~cd}$ & $0.6 \mathrm{efg}$ & $0.22 \mathrm{de}$ \\
\hline & 1.0 & $2.0 \mathrm{~cd}$ & 0.7 defg & $0.26 \mathrm{de}$ \\
\hline \multirow[t]{3}{*}{ PAA } & 0.1 & $1.6 \mathrm{def}$ & $0.8 \mathrm{defg}$ & $0.24 \mathrm{de}$ \\
\hline & 2.0 & $1.9 \mathrm{~cd}$ & $1.6 \mathrm{bc}$ & $0.52 b$ \\
\hline & 4.0 & 1.3efg & $1.4 \mathrm{~cd}$ & $0.40 \mathrm{c}$ \\
\hline \multirow[t]{3}{*}{ IBA } & 0.1 & $1.8 \mathrm{~cd}$ & $1.3 \mathrm{cdef}$ & $0.42 \mathrm{c}$ \\
\hline & 0.5 & $1.0 \mathrm{~g}$ & $0.5 \mathrm{~g}$ & $0.32 \mathrm{~cd}$ \\
\hline & 1.0 & $1.0 \mathrm{~g}$ & $1.2 \mathrm{cdefg}$ & $0.31 \mathrm{~cd}$ \\
\hline \multirow[t]{3}{*}{$\mathrm{AgNO}_{3}$} & 1.5 & $1.9 \mathrm{~cd}$ & $2.1 \mathrm{ab}$ & $0.24 \mathrm{de}$ \\
\hline & 3.0 & $1.7 \mathrm{cde}$ & $0.9 \mathrm{defg}$ & $0.21 \mathrm{de}$ \\
\hline & 4.5 & $1.2 \mathrm{fg}$ & $0.6 \mathrm{fg}$ & $0.18 \mathrm{e}$ \\
\hline \multirow[t]{3}{*}{ Oxalic acid } & 100 & $3.1 \mathrm{a}$ & $2.1 \mathrm{ab}$ & $0.53 b$ \\
\hline & 200 & $2.6 \mathrm{~b}$ & $2.4 \mathrm{a}$ & $0.62 b$ \\
\hline & 300 & $1.8 \mathrm{~cd}$ & $1.3 \mathrm{cde}$ & $0.60 \mathrm{~b}$ \\
\hline \multicolumn{5}{|l|}{ Significance } \\
\hline \multicolumn{2}{|c|}{ Additive type (AT) } & $* * *$ & $* * *$ & $* * *$ \\
\hline \multicolumn{2}{|c|}{ Additive concentrations (AC) } & $* * *$ & $* *$ & NS \\
\hline \multicolumn{2}{|c|}{$\mathrm{AT} \times \mathrm{AC}$} & $* * *$ & $* * *$ & $* * *$ \\
\hline
\end{tabular}

explants were cultured on medium with $\mathrm{GA}_{3}\left(0.5 \mathrm{mg} \mathrm{L}^{-1}\right)$ for $1 \mathrm{wk}$ and then transferred to PGR-free medium with sucrose $\left(60 \mathrm{~g} \mathrm{~L}^{-1}\right)$ for $5 \mathrm{wk}$ to promote shoot formation and elongation, respectively, yielded a low regeneration rate of one shoot per nodal explant (El Far, 2007).

Although the regeneration capacity of nodal sweet potato explants varies according to cultivar and medium composition, the species produces relatively few axillary shoots, when compared to explants from other plant species. For example, 80\%-100\% of 'cv. 11' and 'cv. 44' sweet potato explants only formed single shoots when cultured with BA (1 mg L'; Mohamed et al., 2007). Similarly, most 'Abees' explants only formed single shoots (0.5 mg L'- GA $\mathrm{A}_{3}$; El Far, 2007),

Table 4. Effect of salt strength and exposure duration on shoot multiplication and growth of Ipomoea batatas 'Abees' using a single node explant after 6 wk in culture.

\begin{tabular}{lccccc}
\hline $\begin{array}{l}\text { Salt strength of Murashige } \\
\text { and Skoog medium }\end{array}$ & Culture period & Shoots & Nodes & Shoot length & Fresh weight \\
\hline & Weeks & Nr node $^{-1}$ & Nr explant & cm & g explant $^{-1}$ \\
Full strength & 1 & $2.3 \mathrm{ab}$ & $14.5 \mathrm{~b}$ & $6.9 \mathrm{a}$ & $1.40 \mathrm{ab}$ \\
& 2 & $2.5 \mathrm{ab}$ & $13.7 \mathrm{~b}$ & $5.9 \mathrm{~b}$ & $1.32 \mathrm{ab}$ \\
& 3 & $2.3 \mathrm{ab}$ & $13.1 \mathrm{c}$ & $6.3 \mathrm{a}$ & $1.63 \mathrm{a}$ \\
& 6 & $2.7 \mathrm{ab}$ & $7.8 \mathrm{~d}$ & $3.1 \mathrm{~d}$ & $1.12 \mathrm{~b}$ \\
Half strength & 1 & $2.6 \mathrm{ab}$ & $15.1 \mathrm{a}$ & $6.7 \mathrm{a}$ & $1.18 \mathrm{~b}$ \\
& 2 & $3.1 \mathrm{a}$ & $16.1 \mathrm{a}$ & $6.0 \mathrm{~b}$ & $1.17 \mathrm{~b}$ \\
& 3 & $2.1 \mathrm{~b}$ & $12.6 \mathrm{c}$ & $6.1 \mathrm{~b}$ & $1.47 \mathrm{ab}$ \\
& 6 & $1.9 \mathrm{~b}$ & $7.1 \mathrm{~d}$ & $5.4 \mathrm{c}$ & $1.29 \mathrm{ab}$ \\
\hline Significance & & & & & \\
Salt strength (A) & & $\mathrm{NS}$ & $\mathrm{NS}$ & $\mathrm{NS}$ & $\mathrm{NS}$ \\
Exposure duration (B) & & $*$ & $* * *$ & $* * *$ & $*$ \\
A $\times$ B & & $\mathrm{NS}$ & $\mathrm{NS}$ & $\mathrm{NS}$ & $\mathrm{NS}$
\end{tabular}

${ }^{1}$ All cultures supplemented with $2.0 \mathrm{mg} \mathrm{L}^{-1} \mathrm{BA}$ and $100 \mathrm{mg} \mathrm{L}^{-1}$ oxalic acid.

Values followed by the same letter in the same column are nonsignificantly different according to Tukey's test $(P \leq 0.05)$.

$*, * *, * * *$ Significant at the $0.05,0.01$ and 0.001 probability levels, respectively. NS: Nonsignificant. 
whereas most 'Carmen Rubin' and 'White Triumph' explants only formed four shoots over two multiplication cycles (1 mg L ${ }^{-1} \mathrm{Kin}+1 \mathrm{mg} \mathrm{L}^{-1} \mathrm{GA}_{3}$; Dolinski and Olek, 2013), and most 'Esprit', 'Lady Rosseta', and 'Meridian' explants formed six to seven shoots (1 mg L-1 BA + 0.5-1.0 $\mathrm{mg} \mathrm{L}^{-1} \mathrm{GA}_{3}$; Bhuiyan, 2013).

Because plant species and cultivars differ in salt requirements during axillary shoot multiplication, proper media formulation is imperative when working with diverse cultivar collections (Akin et al., 2018). Varying medium salt strength significantly influence shoot multiplication and growth. However, because neither shoot multiplication nor growth was affected by reducing salt strength in the present study, salt strength can be reduced in 'Abees' axillary shoot multiplication to reduce production costs.

\section{In vitro rooting and acclimatization}

Rooting and acclimatization of in vitro raised shoots is a crucial step in the micropropagation of any plant species. In the present study, the proliferated 'Abees' shoots were easily rooted in half-strength MS medium (100\%) and had produced 3-5 roots after only $3 \mathrm{wk}$, thereby demonstrating that the addition of auxins is unnecessary (Figure 1C). In contrast, previous studies reported that in vitro-propagated shoots of 'Kullufo' and 'Tulla' sweet potato did not root on auxin-free MS medium and that supplementation with IBA $\left(0.25 \mathrm{mg} \mathrm{L}^{-1}\right)$ was required (Mengs et al., 2018). Furthermore, even though shoots of 'Beletech', 'Awass-83', and 'Belela' sweet potato have been observed to root in auxin-free MS medium, the observed root regeneration was lower than that observed in auxin-enriched media (Alula et al., 2018). Meanwhile, previous reports of 'Abees' sweet potato reported that both axillary microshoots (El Far, 2007) and adventitious microshoots (Ali et al., 2017) rooted easily in MS medium without PGRs within 4-6 wk. In the present study, reducing MS basal salts to half-strength stimulated early root initiation (within $10 \mathrm{~d}$ ), which resulted in 100\% rooting at $3 \mathrm{wk}$. Using less MS salts for in vitro rooting improves cost effectiveness but has also been reported to improve rooting in several plant species (Dewir et al., 2016). The plantlets acclimatized with a $96 \%$ survival rate (Figure 1D).

\section{CONCLUSIONS}

The present study investigated the optimal medium formulation for axillary shoot multiplication in Ipomoea batatas 'Abees'. Both cytokinin type and concentration, addition of oxalic acid, medium salt strength, and duration of exposure to plant growth regulators (PGRs) significantly influenced axillary shoot multiplication. Half-strength MS medium that was supplemented with 6-benzyladenine (BA) $\left(2.0 \mathrm{mg} \mathrm{L}^{-1}\right)$ and oxalic acid $\left(100 \mathrm{mg} \mathrm{L}^{-1}\right)$ yielded the greatest shoot proliferation. In this medium, 16 nodes were obtained from single-node explants after $6 \mathrm{wk}$. In addition, all the regenerated shoots rooted in half-strength MS medium and acclimatized without morphological abnormalities or pathological symptoms.

\section{ACKNOWLEDGEMENTS}

The authors extend their appreciation to the Deanship of Scientific Research at King Saud University for funding this work through research group NO (RGP-1438-012) and to the Researchers Support \& Services Unit (RSSU) for their technical support.

\section{REFERENCES}

Aboulila, A.A. 2016. Molecular genetic diversity and efficient plant regeneration system via somatic embryogenesis in sweet potato (Ipomoea batatas (L.) Lam.) Egyptian Journal of Genetics and Cytology 45:347-365.

Aika, E.A.M. 2010. Effect of some addenda manipulation on micropropagation of Musa sp. cv. Grand Naine. PhD Thesis. Department of Biology, Faculty of Education, University of Khartoum, Khartoum, Sudan.

Akin, M., Hand, C., Eyduran, E., and Reed, B.M. 2018. Predicting minor nutrient requirements of hazelnut shoot cultures using regression trees. Plant Cell Tissue and Organ Culture 132:545-559.

Ali, N.M., Rashed, M.A., Abdel-Azem, A.H., Nasr El-Din, T.M., and Metry, E.A. 2017. Regeneration and transformation in Egyptian sweet potato (Ipomoea batatas Lam.) cultivars. Egyptian Journal of Genetics and Cytology 46:329-347.

Ali, A.A., Yossef, T.R., and EL-Banna, A. 2012. Cytokinin-cytokinin interaction ameliorates the callus induction and plant regeneration of tomato (Solanum lycopersicum Mill.) Acta Agronomica Hungarica 60:47-55.

Alula, K., Zeleke, H., and Manikanandan, M. 2018. In vitro propagation of sweet potato (Ipomoea batatas (L.) Lam.) through apical meristem culture. Journal of Pharmacognosy and Phytochemistry 7:2386-2392. 
Bhuiyan, F.R. 2013. In vitro meristem culture and regeneration of three potato varieties of Bangladesh. Research in Biotechnology 4:29-37.

Bovell-Benjamin, A.C. 2007. Sweet potato: a review of its past, present, and future role in human nutrition. Advances in Food and Nutrition Research 52:1-59.

Compton, M.E. 1994 Statistical methods suitable for the analysis of plant tissue culture data. Plant Cell, Tissue and Organ Culture 37:217-242.

Dewir, Y.H., Murthy, H.N., Ammar, M.H., Alghamdi, S.S., Al-Suhaibani, N.A., Alsadon, A.A., et al. 2016. In vitro rooting of leguminous plants: difficulties, alternatives, and strategies for improvement. Horticulture Environment and Biotechnology 57:311-322.

Dewir, Y.H., Nurmansyah, Naidoo, Y., and Teixeira da Silva, J.A. 2018. Thidiazuron-induced abnormalities in plant tissue cultures. Plant Cell Reports 37:1451-1470.

Dolinski, R., and Olek, A. 2013. Micropropagation of sweet potato (Ipomoea batatas (L.) Lam.) from node explants. Acta Scientiarum Polonorum Hortorum Cultus 12:117-127.

El Far, M.M.M. 2007. Optimization of growth conditions during sweet potato micro-propagation. African Potato Association Conference Proceedings 7:204-211.

El Far, M.M.M., El-Mangoury, K., and Elazab, H.E.M. 2009. Novel plant regeneration for Egyptian sweet potato (Ipomoea batatas (L.) Lam.) Abees cultivar via indirect organogenesis stimulated by initiation medium and cytokinin effects. Australian Journal of Basic and Applied Sciences 3:543-551.

FAOSTAT. 2016. Sweet potatoes. Statistical data-base (online) of Food and Agriculture Organization of the United Nations. Available at http://www.fao.org/faostat/en/\#search/Sweet potatoes (accessed September 2018).

Franceschi, V.R., and Nakata, P.A. 2005. Calcium oxalate in plants: formation and function. Annual Review of Plant Biology 56:41-71.

Gaba, V., and Singer, S. 2009. Propagation of sweet potatoes, in situ germplasm conservation and conservation by tissue culture. p. 65-80. In Loebenstein, G., Thottappilly G. (eds.) The sweet potato. Springer, Dordrecht, The Netherlands.

George, E.F., Hall, M.A., and De Klerk, G-J. 2008. Plant propagation by tissue culture. Volume 1. The background. $3^{\text {rd }}$ ed. Springer, Dordrecht, The Netherlands.

Gong, Y., Gao, F., and Tang, K. 2005. In vitro high frequency direct root and shoot regeneration in sweet potato using the ethylene inhibitor silver nitrate. South African Journal of Botany 71:110-113.

Iese, V., Holland, E., Wairiu, M., Havea, R., Patolo, S., Nishi, M., et al. 2018. Facing food security risks: The rise and rise of the sweet potato in the Pacific Islands. Global Food Security 18:48-56.

Kayashima, T. 2002. Oxalic acid is available as a natural antioxidant in some systems. Biochimica et Biophysica Acta 1573:1-3.

Kher, M.M., Nataraj, M., Parmar, H.D., and Buchad, H. 2015. Micropropagation of Merremia quinquefolia (L.) Hallier F. from nodal explants. Journal of Horticultural Research 23:1-16.

Kumar, V., Parvatam, G., and Ravishankar, G.A. 2009. $\mathrm{AgNO}_{3}$ - A potential regulator of ethylene activity and plant growth modulator. Electronic Journal of Biotechnology 12:1-15.

Loebenstein, G. 2009. Origin, distribution and economic importance. p. 9-12. In Loebenstein, G., Thottappilly, G. (eds.) The sweet potato. Springer, Dordrecht, The Netherlands.

Marzouk, N.M., El-Beltagy, A.S., El-Behairy, U.A., Abou-Hussein, S.D., El-Bedewy, R., and El-Abd, S.O. 2011. Performance of selected sweet potato germplasms under Egyptian conditions. Australian Journal of Basic and Applied Sciences 5:18-21.

Masekesa, R.T., Gasura, E., Matikiti, A., Kujeke, G.T., Ngadze, E., Icishahayo, D., et al. 2016. Effect of BAP, NAA and GA either alone or in combination, on meristem culture and plantlet establishment in sweet potato (cv Brondal). African Journal of Food and Agriculture Development 16:10653-10669.

Mengs, B., Chimdessa, M., and Abraha, E. 2018. In vitro propagation of sweet potato (Ipomoea batatas (L.) Lam.) through lateral bud culture. International Journal of Innovative Pharmaceutical Science and Research 6:1-12.

Mohamed, M.F., Abdalla M.M.A., and Damarany, A.A.M. 2007. Differential axillary-bud proliferation responses of two sweet potato cultivars to benzyl adenine and thidiazuron. Assiut University Bulletin for Environmental Researches 10:21-30.

Mukherjee, A., Naskar, S.K., Rao, K.R., and Ray, R.C. 2012. Sweet potato: gains through biotechnology. Fruit, Vegetable and Cereal Science and Biotechnology 6:30-42.

Murashige, T., and Skoog, F. 1962. A revised medium for rapid growth and bio assays with tobacco tissue cultures. Physiologia Plantarum 15:473-497.

Mvuria, J.M., and Ombori, O. 2014. Low cost macronutrients in the micropropagation of selected sweet potato [Ipomoea batatas (L.) Lam.] varieties. Journal of Agriculture and Environmental Sciences 3:89-101.

Teixeira da Silva, J.A., Giang, D.T.T., and Tanaka, M. 2007. Sweet potato: from glass to greenhouse. Acta Horticulturae 748:247-257.

Teow, C.C., Truong, V-D., McFeeters, R.F., Thompson, R.L., Pecota, K.V., and Yencho, G.C. 2007. Antioxidant activities, phenolic and $\beta$-carotene contents of sweet potato genotypes with varying flesh colours. Food Chemistry 103:829-838.

Vettorazzi, R.G., Carvalho, V.S., Sudré, C.P., and Rodrigues, R. 2017. Developing an in vitro optimized protocol to sweet potato landraces conservation. Acta Scientiarum Agronomy 39:359-367. 